\title{
Industrial Grinding Estimation of Blended Ore from Porphyry Copper Deposit
}

\author{
Irena Grigorova ${ }^{1}$, Marin Ranchev ${ }^{2}$, Teodora Yankova ${ }^{3}$, Ivan Nishkov ${ }^{4 *}$ \\ ${ }^{1}$ Associate Professor DSc, University of Mining and Geology "St. Ivan Rilski”, Department of Mineral \\ Processing and Recycling, Sofia, Bulgaria. \\ ${ }^{2}$ Research Assistant Professor Dr, University of Mining and Geology "St. Ivan Rilski”, Department of Mineral \\ Processing and Recycling, Sofia, Bulgaria. \\ ${ }^{3}$ Assistant Professor Dr University of Mining and Geology "St. Ivan Rilski", Department of Mineral Processing \\ and Recycling, Sofia, Bulgaria. \\ ${ }^{4}$ Professor, Dr, University of Mining and Geology "St. Ivan Rilski”, Department of Mineral Processing and \\ Recycling, Sofia, Bulgaria. \\ *Corresponding Author: Dr. Ivan Nishkov, Department of Mineral Processing and Recycling, University \\ of Mining and Geology "St. Ivan Rilski”, 1700 Sofia, Bulgaria.
}

\begin{abstract}
In order to provide an uniform feed to the processing plant, the mined from a porphyry copper deposit ore is blended in the following proportions: Propylites 31-35\%; Argilizites 30-33\%; Secondary quartzites 30-36 \% (roughly 1:1:1). Those three types of ore differ in particle size, as well as in mineral composition. The variations in the mineral composition of the treated ore are due to the varying content of primary and secondary copper sulphides as well as of oxide minerals. There are also significant amounts of clay minerals in the ore. A recent research program shows that the propylite compound in the feed ore will increase significantly. Approximately $68-70 \%$ of the ore blend, entering the processing plant will be composed of propylites, $28 \%$ - argilizites and 4\% secondary quartzites. Therefore, for the purpose of analyze and evaluate the performance of comminution equipment in the processing plant, an industrial experiment for several work shifts with the above mentioned percentage content of the run of mine have been conducted. Furthermore, one of the autogenous mill (AG) was converted in semi-autogenous mill (SAG) with adding 8\% grinding media, appropriate lifters and liners profile, and discharge grates with 15 and 30 mm openings. The aim of the industrial experiment was to assess the benefits of SAG mill grinding, and to evaluate the grinding and classification efficiency of the associated ball mills closed with hydrocyclones. The particle size distribution curves showed that there is no significant difference between the current ore blend (1:1:1) and the experimental mixture (68-70\% Propylites). Sampling was carried out in order to determine the distribution of the material flows (quantitative assessment) to the subsequent comminution sections, such as secondary and tertiary crushing, ball mill grinding and classification. The results showed that a combination of semi-autogenous and ball mill grinding is an appropriate way of comminution circuit optimization.
\end{abstract}

Keywords: $A G, S A G$, ore blend, industrial experiment, concentrator.

\section{INTRODUCTION}

\subsection{Geology and Mineralogy}

The studied porphyry copper deposit is located mainly in the volcanics and intrusive, granitoids rocks. Ore mineralization forms an ore body, presented by large stock work and it has ellipsoidal contours. The ore mineralization is forms mainly fine veinlets in craks and mineral disseminations. Pyrite and chalcopyrite are the main ore minerals in the primary sulphide ores. Oxidation mineralization and secondary copper sulphides are also present in the deposit.

The volcanic and intrusive rocks that host the porphyry copper deposit were affected by intensive hydrothermal alterations. Propylitic, argillic, sericitic and advanced argillic alteration (secondary quartzite formation) types are established as well as some transitional alteration types.

Relatively complex ore mineralogy, containing pyrite and various clay minerals was established in the deposit. Three species of ore represent the concentrator feed material - propylites (PR), secondary 
quartzites (SQ) and argillizites (ARG). Those three types of ores showed significant difference in their particle size, as well as in the mineral composition.

\subsection{Comminution Circuits}

Comminution is a fundamental part of the mineral processing operation and its proper operation and design is vital to ensure that the plant is operating efficiently. Comminution can account for up to $75 \%$ of the total energy consumed by a conventional concentrator. Most of this energy is the electrical energy required to operate large grinding mills, such as ball and rod mills, AG and SAG mills [5].

The influence of feed size on mill performance naturally follows from the fact that a considerable part of the grinding media (especially in autogenous mills) derives from the feed ore. Any change in the feed distribution will therefore result in a change in the grinding media size distribution. This in turn will affect the breakage characteristics of the mill [6].

Assuming a slight change of the mill breakage characteristics, the mill charge level will be also changed, which will certainly affects the mill power draw. As a result, the measured AG/SAG mill power draw often varies widely with time. This is one of the significant differences in operation between the AG/SAG mill and the ball/rod mill, power draw of the latter being relatively stable. In response to the variation in feed size and hardness, the mill feed rate has to be changed significantly [7].

The comminution processes such as crushing, grinding, screening and classification are commonly prior to the mineral separation processes. Very important part of the comminution circuits are the sizing devices, which strongly influence the performance of the circuit. Ball mill circuits, operating with hydro cyclones are highly recognized as the most commonly used equipment in the mineral processing industry. In addition, in their analysis of ball mill closed circuits, Jankovic and Valery analyzed in great details the effect of circulating load and classification efficiency on the closed grinding circuit performance [2].

The comminution circuit of the concentrator consists of three jaw crushers, five AG mills in "open" circuit configuration with double screen trommel attached to the mill, five cone crushers for secondary ( 2 crushers) and tertiary ( 3 crushers) crushing stage and nine ball mills in closed circuit with classifying hydro cyclones. The cyclone overflow feeds the flotation stage with a grind size P80 of 100 microns. The final copper concentrate assaying approximately $23 \% \mathrm{Cu}$ is pressure filtered before transported to the smelter.

The objective of this study is to assess the behavior of the comminution equipment in the concentrator to changes in the AG-Ball mill circuit feed characteristics. This was achieved by changing the percentage content of the three types of rocks (PR, SQ and ARG) in the primary crushed ore, entering the processing plant. Furthermore, an industrial experiment including the converting of one of the existing AG mill to SAG mill, in order to evaluate the AG mill - Ball mill (AG-BM) and SAG mill Ball mill (SAG-BM) circuits performance and to compare the collected operational data have been conducted.. The results obtained from this industrial comparison, are presented in this work.

\section{METHODS}

\subsection{Particle Size Distribution and Mineralogical Studies}

Representative samples from the AG mill feed conveyer belt were collected and sieved to determine the particle size distribution in both experimental and current ore blend. It was important to understand, whether the change in the ore composition will affect the grain size distribution of the ore fed to the circuit. Mineralogical studies on representative samples of the three types of ore, processed at the concentrator were carried out. From each ore sample (PR, SQ and ARG) the following grainsize fractions were obtained: $-3.0+2.0 \mathrm{~mm} ;-2.0+1.0 \mathrm{~mm} ;-1.0+0.40 \mathrm{~mm}$; $-0.40+0.20 \mathrm{~mm}$; $0.20+0.10 \mathrm{~mm} ;-0.10+0.080 \mathrm{~mm}$ and $-0.080 \mathrm{~mm}$. The mineralogical studies have been accomplished using optical microscope.

\subsection{Sampling Campaign}

\section{- Ore Blend Investigation}

Sampling campaigns during the industrial investigations with the current and experimental ore blend were conducted. Dry ore samples in order to determine the particle size distribution in the AG mill feed have been taken. Furthermore, until the end of the experiment ( 27 shifts) an industrial data such 
as mass flow measurements, obtained from the electromechanical conveyer belt weighers and mass flow meters, have been collected with the aim to evaluate the AG mill products distribution $(\mathrm{t} / \mathrm{h})$.

\section{- AG to SAG Mill Industrial Investigation}

Throughout the industrial investigation, several sampling surveys on both AG-BM and SAG-BM grinding circuits were conducted. The comminution circuit, along with the sampling points is shown in Figure 1. The circuits were sampled over a period of 4 hours, during which several samples were taken in different points as shown in figure 2. Manual sampling of the process streams such as AG/SAG mill feed, trommel screen undersize product $(-5.00+0.00 \mathrm{~mm})$, ball mill discharge and cyclone feed, overflow and underflow have been conducted in order to characterize the particle size distribution in the products and to carry out mass balancing of grinding circuits. Furthermore, an industrial data such as mill power, AG mill, Ball mill, trommel screen products, cyclone feed, underflow and overflow flow rates were taken during the sampling campaigns.

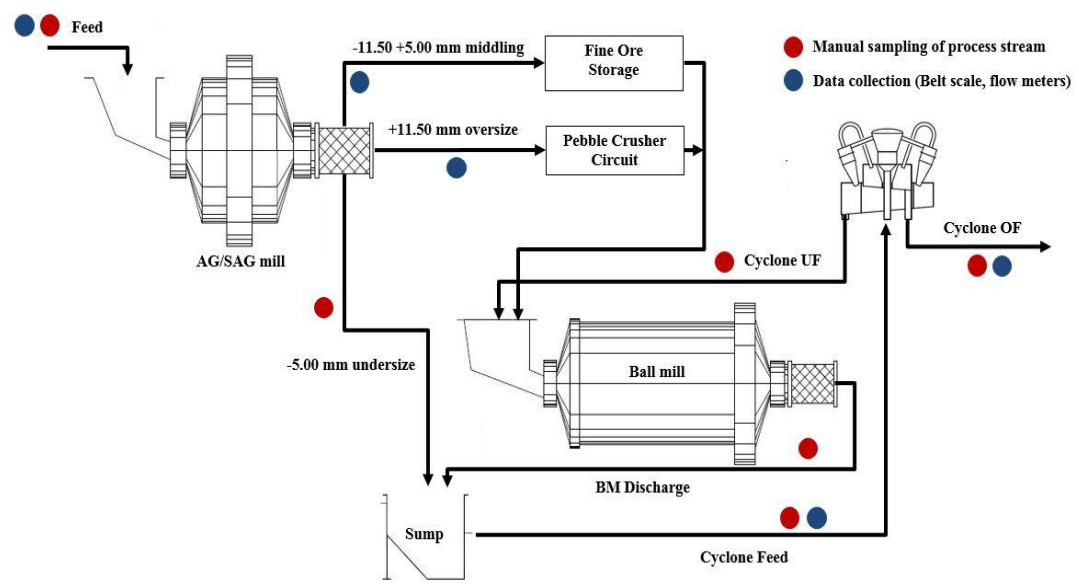

Figure1. AG/SAG-Ball mill experimental flow sheet with sampling points

\subsection{AG to SAG Conversion}

\section{- Mill Design}

During the industrial experiments two discharge grate apertures: $15 \times 30 \mathrm{~mm}$ and $30 \times 42 \mathrm{~mm}$ have been tested. In addition, an appropriate rubber liner and lifters (Figure 2) and steel balls $-100 \mathrm{~mm}$ in diameter ( $8 \%$ ball charge volume) were provided. The experiments were conducted to assess whether a higher throughput and finer final products could be achievable.

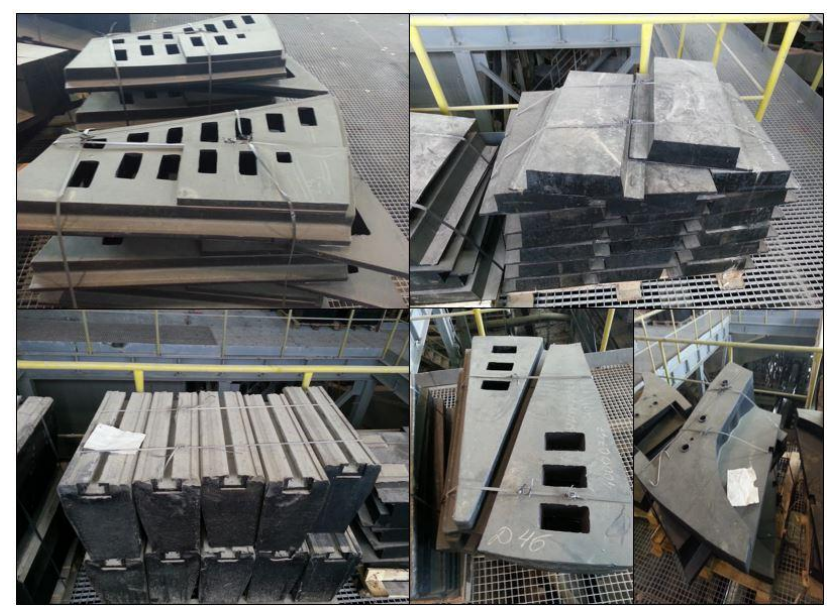

Figure2. View of the rubber liners, lifters and discharge grate

\section{EXPERIMENTAL}

\subsection{Circulating Load and Classification Efficiency}

Hydro cyclones are one of the most frequently used size separation devices in today's mineral processing plants, mainly due to their simplicity, adaptability to changes in operating conditions and high capacity per unit area occupied [4]. Sizing devices such as hydro cyclones are important 
components of most comminution circuits. Therefore, an essential element in assessing the performance of such devices and the performance of the comminution equipment is the measurement and representation of particle size distribution [6]. It has been suggested that with higher circulating load the capacity of the operating ball mills tends to increase, however, this increase is restricted due to poor classification efficiency. Classification efficiency is defined as the percent of final product size material recovered to the classifier fine stream [3]

It is well known that the most common cause of poor ball mill operation is poor classifier performance. The effect of closed circuit operation is to produce fewer coarse particles without producing excessive fine product. Therefore, it is very important to understand that circulating load (CL) is set by the magnitude of the difference in size distribution between classifier product and classifier feed. A lower CL will allow a longer mill residence time and a finer ball mill discharge. It will also allow already finished products more opportunities to be broken further. Hence, the optimum CL will provide a good compromise over grinding and minimization of coarse particles in the mill discharge [6].

In order to evaluate the classification efficiency and circulating load for both grinding circuits configuration (AG+BM and SAG+BM), samples from the cyclone feed, overflow and underflow during the sampling surveys have been taken.

Based on size analysis the classification efficiency can be calculated as follow:

$\mathrm{E}_{\mathrm{oi}}=\frac{100 \cdot \mathrm{W}_{\mathrm{oi}} \cdot\left(\mathrm{W}_{\mathrm{fi}}-\mathrm{W}_{\mathrm{ui}}\right)}{\mathrm{W}_{\mathrm{fi}} \cdot\left(\mathrm{W}_{\mathrm{oi}}-\mathrm{W}_{\mathrm{ui}}\right)}$

where $\mathrm{W}_{\mathrm{fi}}, \mathrm{W}_{\mathrm{oi}}$ and $\mathrm{W}_{\mathrm{ui}}$, determined by size analysis of samples, are the proportions by weight of material of size $\mathrm{i}$ in the feed, overflow and underflow solids, respectively.

A calculation, based on the screen size analysis of the pulps, instead of the dilution ratios is believed to be more precise method for determining the circulating load (CL) of a grinding circuit:

$\mathrm{CL}=\frac{\mathrm{W}_{\mathrm{oi}}-\mathrm{W}_{\mathrm{fi}}}{\mathrm{W}_{\mathrm{fi}}-\mathrm{W}_{\mathrm{ui}}} \cdot 100 \%$

The connection between classification efficiency and circulating load, might be illustrate as follows: [2], [1].

$\mathrm{E}=\frac{\mathrm{W}_{\mathrm{oi}}}{\mathrm{W}_{\mathrm{oi}}+\mathrm{W}_{\mathrm{ui}} \cdot \frac{\mathrm{CL}}{100}} \cdot 100 \%$

\section{RESULTS AND DISCUSSION}

\subsection{Particle Size Distribution}

The results from the particle size distribution analysis did not show any significant differences in their F80. The distribution of large particles such as $+80 \mathrm{~mm}$ that are able to break smaller rocks could be seen in Figure 3: Current blend ore $+80 \mathrm{~mm}-6.60 \%$, and experimental blend $+80 \mathrm{~mm}-10.83 \%$.

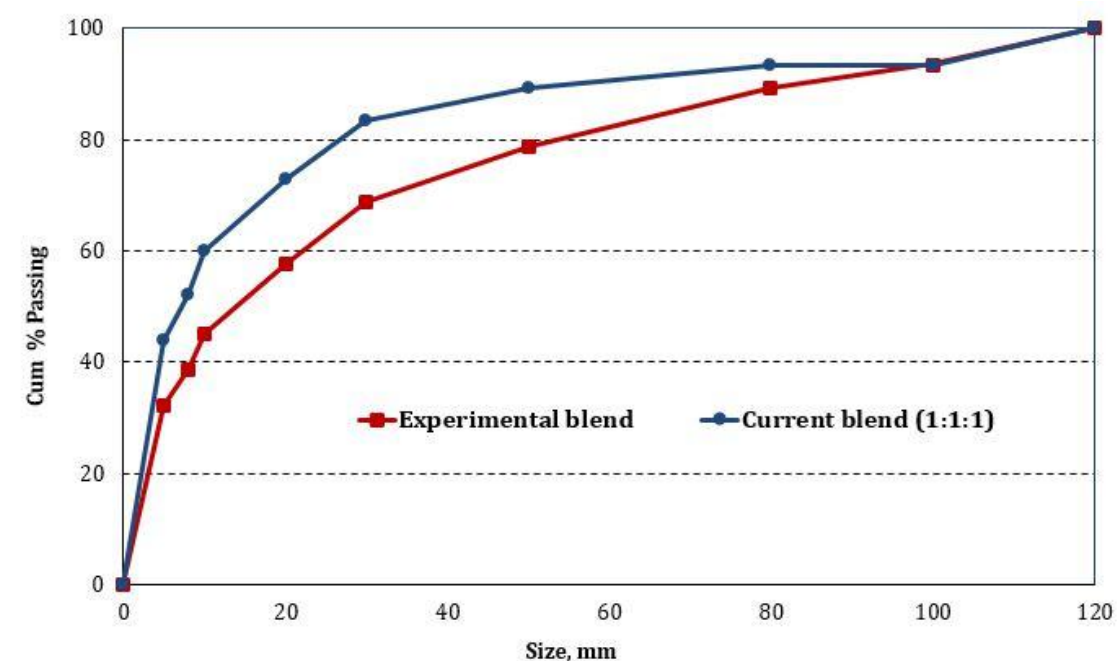

Figure3. Particle size distribution of AG mill feed ore blend - experimental and current blend 


\subsection{Mineralogical Analysis of the Three Types of Ores - Propylites, Secondary Quartzites and Argillizites}

\section{Propylites}

The main non-metallic minerals are plagioclase, quartz, chlorite, sericite and probably clay phases, and the subordinate minerals - K-feldspar, epidote and others. The ore minerals are mostly presented by pyrite, primary copper sulphides (chalcopyrite, bornite), secondary copper sulphides (bornite, chalcocite, covellite), and copper oxides (cuprite).

\section{Secondary Quartzites}

Ore minerals are represented by pyrite, primary copper sulphides (chalcopyrite) and secondary copper sulphides (chalcocite, covelitte). The main non-metallic minerals in the studied sample are quartz, sericite and clay phases. As subordinate - plagioclase, single particles of chlorite and actinoliteare presented. By decreasing the size of the fractions, the amount of ore minerals increases.

\section{Argillizites}

The main non-metallic minerals are represented by quartz, clay minerals, sericite. As a subordinate plagioclase, gypsum and single particles of chlorite could be found. Ore minerals are represented by pyrite, primary and secondary copper sulphides. Covelitte and bornite rarely occur.

High degree of copper minerals liberation is achieved in the fractions below $0.100 \mathrm{~mm}$. In the fine fractions $-0.080+0.00 \mathrm{~mm}$, a significant amount of clay minerals, quartz, sericite and plagioclase could be found.

\section{AG to SAG Conversion}

The industrial experiment with $15 \times 30 \mathrm{~mm}$ discharge grate showed unsatisfactory results, with respect to SAG mill throughput. Therefore, the experiment was discontinued and new grate with increased open area (30x42 mm openings) was installed. The summarized results, presented below were obtained from the industrial experiments performed with 30x42 mm discharge grate.

The obtained results from the compared grinding circuits (AG mill + Ball mill; Converted AG to SAG mill + Ball mill) are shown in the Tables $1-4$ below.

Table1. Summarized results from the AG and SAG mill sampling campaign and monitored circuit data

\begin{tabular}{|c|c|c|c|c|c|c|c|}
\hline \multirow[t]{2}{*}{ Mill } & \multirow{2}{*}{$\frac{\text { Feed }}{\mathrm{t} / \mathrm{h}}$} & \multicolumn{2}{|c|}{$\begin{array}{c}\text { Undersize } \\
-5.00+0.00 \mathrm{~mm}\end{array}$} & \multicolumn{2}{|c|}{$\begin{array}{c}\text { Middling } \\
-11.50+5.00 \mathrm{~mm}\end{array}$} & \multicolumn{2}{|c|}{$\begin{array}{l}\text { Oversize } \\
+11.50 \mathrm{~mm} \\
\end{array}$} \\
\hline & & $\mathrm{t} / \mathrm{h}$ & $80 \mu \mathrm{m}(\%)$ & $\mathrm{t} / \mathrm{h}$ & $80 \mu \mathrm{m}(\%)$ & $\mathrm{t} / \mathrm{h}$ & $80 \mu \mathrm{m}(\%)$ \\
\hline AG mill & 384.00 & 169.31 & 22.64 & 65.36 & - & 149.34 & - \\
\hline SAG mill & 311.00 & 216.52 & 22.06 & 66.06 & - & 28.43 & - \\
\hline
\end{tabular}

The results from Table 1 show some of the pros and cons of the experimental SAG mill performance, such as: lower feed rate $(311.00 \mathrm{t} / \mathrm{h})$ compared to the AG mill, but higher throughput of undersize product $(216.52 \mathrm{t} / \mathrm{h})$. The mass $(\mathrm{t} / \mathrm{h})$ of the oversize product from the trommel screen $(+11.50 \mathrm{~mm})$, conveyed to the secondary-tertiary crushing stage is significantly reduced, which is a serious advantage in terms of more uniform fed to the department. From previous studies of the concentrator comminution it was found that, the wet screening of crushed ore section is the bottleneck on the recirculating fine crushing circuit.

Table2. Summary of the Grinding Circuits Survey Results (AG+BM1; SAG+BM2)

\begin{tabular}{|c|c|c|c|c|c|c|c|c|}
\hline \multirow{2}{*}{ Configuration } & \multicolumn{2}{|c|}{ Total BM feed } & \multicolumn{2}{c|}{ BM Discharge } & \multicolumn{2}{c|}{ Cyclone OF } & \multicolumn{2}{c|}{ Cyclone UF } \\
\cline { 2 - 9 } & $\mathrm{t} / \mathrm{h}$ & $80 \mu \mathrm{m}(\%)$ & $\mathrm{t} / \mathrm{h}$ & $80 \mu \mathrm{m}(\%)$ & $\mathrm{t} / \mathrm{h}$ & $80 \mu \mathrm{m}(\%)$ & $\mathrm{t} / \mathrm{h}$ & $80 \mu \mathrm{m}(\%)$ \\
\hline $\begin{array}{c}\text { Ball Mill 1 } \\
(\mathrm{AG}+\mathrm{BM} 1)\end{array}$ & 195.31 & 20.07 & 895.85 & 18.03 & 195.31 & 59.26 & 869.9 & 9.67 \\
\hline Ball Mill 2 & 255.52 & 19.10 & 1197.50 & 16.63 & 255.5 & 59.20 & $\begin{array}{c}1185 . \\
50\end{array}$ \\
\hline (SAG + BM 2) & & & & & & & 8.26 \\
\hline
\end{tabular}


Table3. Summary of the estimated $A G / S A G+B M$ operating parameters

\begin{tabular}{|c|c|c|c|c|c|}
\hline Configuration & $\begin{array}{c}\text { Newly formed fraction } \\
80 \mu \begin{array}{c}\text { \% } \text { (in the mill } \\
\text { discharge) }\end{array}\end{array}$ & \multicolumn{2}{|c|}{ Cyclone feed } & Circulating load & $\begin{array}{c}\text { Classification } \\
\text { efficiency }\end{array}$ \\
\cline { 2 - 6 } & $\mathrm{t} / \mathrm{h}$ & $\mathrm{t} / \mathrm{h}$ & $80 \mu \mathrm{m} \%$ & $\%$ & $\%$ \\
\hline AG mill + BM 1 & 131.96 & 1065.20 & 18.80 & 443.15 & 57.91 \\
\hline SAG mill & 167.05 & 1414.00 & 17.50 & 453.4 & 61.24 \\
\hline
\end{tabular}

Table4. Summary of the calculated operating parameters for the ball mills

\begin{tabular}{|c|c|c|c|c|c|}
\hline \multirow{2}{*}{ Ball mill } & \multicolumn{3}{|c|}{ Relative throughput, $\mathrm{t} / \mathrm{m}^{3} \mathrm{~h}$} & \multicolumn{2}{c|}{ Grinding efficiency, $\mathrm{t} / \mathrm{kWh}$} \\
\cline { 2 - 6 } & Ball mill feed & $\begin{array}{c}\text { Newly formed } \\
\text { fraction } 80 \mu \mathrm{m}(\%)\end{array}$ & $\begin{array}{c}\text { Energy } \\
\text { consumption } \mathrm{kW} / \mathrm{h}\end{array}$ & $\begin{array}{c}\text { Ball mill } \\
\text { feed }\end{array}$ & $\begin{array}{c}\text { Newly formed } \\
\text { fraction } 80 \mu \mathrm{m}(\%)\end{array}$ \\
\hline BM 1 & 2.441 & 1.649 & 1848.0 & 0.106 & 0.071 \\
\hline BM 2 & 3.194 & 2.088 & 1969.0 & 0.130 & 0.085 \\
\hline
\end{tabular}

The calculated operating parameters (relative throughput and grinding efficiency) confirm the advantages of the experimental grinding circuit (SAG mill + Ball mill, closed with hydrocyclone), despite the slightly higher power consumption (Table 4).

\section{CONCLUSION}

The results from the experiments with the current and experimental ore blends showed a negligible difference in particle size distribution. However, it is recommended to determine, whether there is any significant variation in the physical properties of the experimental ore blend, such as hardness and density, which could affect the overall mill grind ability.

During the industrial experiment through which the current AG mill - Ball mill grinding circuit was compared with SAG mill (available AG converted to SAG) - Ball mill configuration, the following operating parameters have been determined: higher throughput $(\mathrm{t} / \mathrm{h})$ of the experimental grinding circuit (SAG+BM) leading to increased quantity of newly formed particles of the desired size of 80 $\mu \mathrm{m}$. Furthermore, the estimated classification efficiency and circulating load, which is well-known to have a critical effect on the ball mill circuits operation, showed that the proposed configuration (SAG mill + Ball mill) could achieved acceptable values, that can be further improved.

In addition, during the course of the industrial experiment, it was once again found that the wet screening of the secondary-tertiary crushing department is a serious obstacle (bottleneck), hinders the achievement of a higher plant throughput.

The improvement of any comminution circuit could be done by optimization of various operating parameters, such as: grate parameters (open area, grate aperture and position of holes on grate), ball charge volume and ball size, mill speed, mill liners, etc. In addition, changes in some primary variables associated with the conventional grinding circuits, for instance - feed rate and circulating load, size distribution and hardness of the ore, classifier water addition, slurry densities and solids concentration, etc., could affect the performance of autogenous (AG), semi-autogenous (SAG) and ball mills.

In general, based on the results from the industrial experiment, conducted in the processing plant the semi-autogenous grinding (SAG) with ball mill combination is the most effective comminution solution for the concentrator.

\section{REFERENCES}

[1] Hukki, R. T., and H. Allenius. 1968. A quantitative investigation of the closed grinding circuit. Trans. AIME 241 (4): 482-487.

[2] Jankovic. A. and W. Valery. 2012. Closed Circuit Ball Mill - Basics Revisited Minerals Engineering, http://dx.doi.org/10.1016/j.mineng.2012.11.006.

[3] Jankovic, A., Valery, W., Sonmez, B., Oliveira, R. 2014. Effect of circulating load and classification efficiency on HPGR and ball mill capacity. XXVII International Mineral Processing Congress, 2014 Oct. 20-24, Santiago, Chile, Proceedings, Chapter 9.

[4] Lynch, A. J. 1977. Mineral crushing and grinding circuits: their simulation, optimisation, design and control. $1^{\text {st }}$ ed. Furstenau, D.W. Elsevier Scientific Publishing Company, 87-90. 
[5] Musa, F., Morrison, R. 2009. A more sustainable approach to assessing comminution efficiency. Minerals Engineering, Vol. 22 (7): 593-601.

[6] Napier-Munn, T. J., Morrell, S., Morrison, R. D., Kojovic, T. 2005. Comminution Circuits - Their Operation and Optimization. $2^{\text {nd }}$ ed. Napier-Munn, T.J. Brisbane: Mineral, JKMRC, The University of Queensland, Brisbane; p. 178

[7] Wills, B. A., Napier-Munn, T. 2006. Mineral Processing Technology: An Introduction to the Practical Aspects of Ore Treatment and Mineral Recovery. $7^{\text {th }}$ ed. Napier-Munn, T. J. Elsevier Science \& Technology Books. Butterworth-Heinemann, Oxford., The University of Queensland, p. 444.

\section{AUTHORS' BIOGRAPHY}

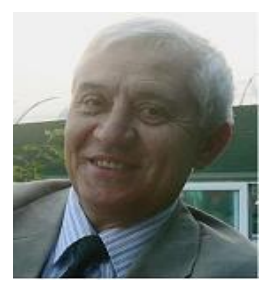

Professor Dr. Ivan Nishkov, Experience of Mineral Processing and Recycling over 40 years at Central Laboratory of Mineral Processing, Bulgarian Academy of Science, private business and University of Mining and Geology "St. Ivan Rilski".

Now: Head of Central Laboratory of Raw Materials Processing and Waste Management, University of Mining and Geology "St. Ivan Rilski”, Sofia, Bulgaria. Professor in Department of Mineral Processing and Recycling, University of Mining and Geology "St. Ivan Rilski", Sofia, Bulgaria. President of company MINTECH. Representative of Bulgaria in Advisory Committee of International Mineral Processing Congress. Representative of Bulgaria in International Scientific Committee of Balkan Mineral Processing Congress. Member of Balkan Academy of Science on Mineral Technologies.

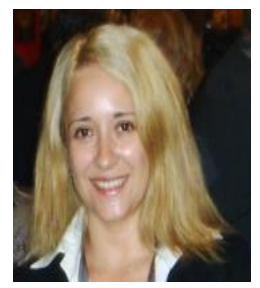

Associate Professor DSc Irena Grigorova, Head of Mineral Processing and Recycling Department, University of Mining and Geology "St. Ivan Rilski”, Sofia, Bulgaria. Member of Balkan Academy of Science on Mineral Technologies.

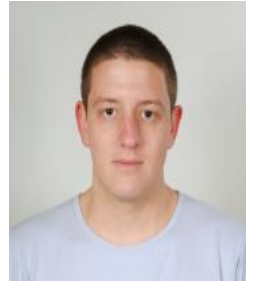

Dr. Mag. Eng. Marin Ranchev, Research Assistant Professor in Department of Mineral Processing and Recycling, University of Mining and Geology "St. Ivan Rilski”, Sofia, Bulgaria.

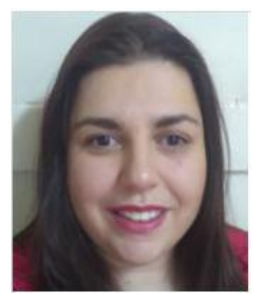

Dr. Mag. Eng. Teodora Yankova, Assistant Professor in Department of Mineral Processing and Recycling, University of Mining and Geology "St. Ivan Rilski", Sofia, Bulgaria.

Citation: Irena Grigorova et.al, (2018). Industrial Grinding Estimation of Blended Ore from Porphyry Copper Deposit, International Journal of Mining Science (IJMS), 4(2), pp.16-22, DOI: http://dx.doi.org/ 10.20431/2454-9460.0402002

Copyright: ( 2018 Authors. This is an open-access article distributed under the terms of the Creative Commons Attribution License, which permits unrestricted use, distribution, and reproduction in any medium, provided the original author and source are credited 